\title{
Dimensi Dakwah Islam dalam Budaya Nyepuh
}

\author{
Faisal Muzzammil ${ }^{*}$ \\ 1 STAI DR. KHEZ. Muttaqien Purwakarta, Indonesia; faisal@staimuttaqien.ac.id \\ * Correspondence
}

Received: 2021-01-18; Accepted: 2021-04-27; Published: 2021-04-30

\begin{abstract}
Nyepuh culture is a blend of local wisdom and universal Islamic teachings. The strong interrelation between culture and religion in the reality of Ciomas Village community life seems to be a single dual that is difficult to distinguish. Knowledge is integrated with trust and values, which determines the situation and behavior conditions of Ciomas Village community members. This study aims to reveal the dimensions of Islamic da'wah in the culture of the Nyepuh from the aspects of ideafacts, artifacts, and sociofacts. The theoretical basis of this study refers to the theory of the Three Cultural Beings of J.J. Hoenigman, namely: Ideafacts, Artifacts, and Sociofacts. The findings in the locus study show that: First, the ideafact culture manifestation in the gild culture which has the dimensions of Islamic da'wah includes Mulung Pangpung, Nalekan, Ngasakan, Clean Village, Nya'angan, and Meungkeut Nyere. Second, the artifact culture manifestations in the gild culture with the dimensions of Islamic da'wah are the Sacred Tomb, Golden Geger Water, Pangpung, Tumpeng Rice, Nyere, and Beubeutian. Third, the form of sociofact culture in gild culture has dimensions of Islamic da'wah: Relationship with Humans, Relationship with Nature, and Relationships with God.
\end{abstract}

Keywords: Traditional culture; Islamic da'wah; cultural manifestation

\begin{abstract}
Abstrak: Budaya nyepuh merupakan perpaduan antara local wisdom dan ajaran agama Islam secara universal. Kuatnya interrelasi antara budaya dan agama dalam realitas kehidupan masyarakat Desa Ciomas seolah menjadi dwi tunggal yang sukar dibedakan, di dalamnya tersimpul pengetahuan yang terpadu dengan kepercayaan dan nilai, yang menentukan situasi dan kondisi perilaku anggota masyarakat Desa Ciomas. Studi ini bertujuan untuk mengungkapkan dimensi dakwah Islam dalam budaya nyepuh dari aspek ideafacts, artifacts, dan sociofacts. Landasan teori dari studi ini mengacu pada teori tentang Tiga Wujud Kebudayaan dari J.J. Hoenigman, yakni: Ideafacts, Artifacts, dan Sociofacts. Hasil temuan di locus studi menunjukkan bahwa: Pertama, wujud kebudayaan ideafact dalam budaya nyepuh yang memiliki dimensi dakwah Islam meliputi: Mulung Pangpung, Nalekan, Ngasakan, Bersih Desa, Nya'angan, dan Meungkeut Nyere. Kedua, wujud kebudayaan artifact dalam budaya nyepuh yang memiliki dimensi dakwah Islam ialah: Makam Keramat, Air Geger Emas, Pangpung, Nasi Tumpeng, Nyere, dan Beubeutian. Ketiga, wujud kebudayaan sociofact dalam budaya nyepuh yang memiliki dimensi dakwah Islam: Hubungan dengan Manusia, Hubungan dengan Alam, dan Hubungan dengan Tuhan.
\end{abstract}

Kata Kunci: Budaya tradisional; dakwah Islam; wujud kebudayaan

\section{Pendahuluan}

Masyarakat desa mewarisi berbagai tradisi dan upacara adat yang rutin dilakukan (Ritchie \& Hatoum, 2020). Budaya masyarakat tersebut seringkali merupakan perpaduan antara local wisdom dan ajaran agama (T. Rahman, 2013). Kuatnya interrelasi antara budaya dan agama dalam realitas kehidupan masyarakat seolah menjadi dwi tunggal yang sukar dibedakan, di dalamnya tersimpul pengetahuan yang terpadu dengan kepercayaan dan nilai, yang menentukan situasi dan kondisi 
perilaku anggota masyarakat tersebut (M. T. Rahman, 2018). Hal itu dapat dilihat pada budaya nyepuh di Desa Ciomas, Kecamatan Panjalu, Kabupaten Ciamis, Jawa Barat.

Budaya nyepuh ini secara historis memiliki tujuan untuk mengenang perjuangan Kyai Penghulu Gusti, tokoh penyebar agama Islam di wilayah Panjalu. Menurut keterangan Dede Suhendar, salah satu kuncen makam Kyai Panghulu Gusti, tradisi nyepuh ini dilakukan satu tahun sekali menjelang masuknya bulan suci ramadhan. Pada kegiatan nyepuh tersebut, semua masyarakat dianjurkan untuk memakai pakaian yang serba putih. Tradisi nyepuh tersebut, diawali dengan berkumpulnya seluruh masyarakat di lapangan Desa. Kemudian dilanjutkan dengan berjalan kaki mengelilingi Desa melewati rumah-rumah penduduk sambil melantutunkan Sholawat Nabi saw. Setelah mengelilingi Desa, masyarakat menuju ke atas bukit tempat dimakammnya Kyai Penghulu Gusti, tokoh penyebar Islam di Desa Ciomas, untuk melakukan akfitas ziarah (Wawancara 16 Sya'ban 1440 H). Ujang Parman, salah satu sesepuh Desa Ciomas, menuturkan bahwa pada kegiatan nyepuh tersebut di dekat lokasi makam Kyai Penghulu Gusti ada sebuah lapangan yang sebelumnya sudah disediakan 3 (tiga) nasi tumpeng. Tiga nasi tumpeng tersebut dibuat oleh 17 orang perempuan yang berasal dari Desa Ciomas. Bilangan 3 (tiga) mempunyai makna dan melambangkan persaudaran, keimanan, dan ketaqwaan. Perempuan yang membuat nasi tumpeng untuk kegiatan nyepuh ini, selama proses pembuatan dan pengolahannya dilarang untuk berbicara sampai nasi tumpengnya siap disajikan (Wawancara 16 Sya'ban 1440 H). Berdasarkan keterangan Ujang Paraman tersebut, secara filosofis dapat dikatakan bahwa tradisi nyepuh ini bertujuan untuk mengungkapkan rasa syukur dan membersihkan jiwa manusia.

Realitas dan fenomena tradisi nyepuh yang dilakukan oleh masyarakat Desa Ciomas tersebut, menjadi menarik dan penting untuk diteliti. Dianalis dari perspektif Antropologi, tradisi nyepuh tersebut kaya akan makna budaya yang harus dijaga dan dilestarikan; sedangkan di sisi lain, dianalis dari perspektif ajaran agama Islam, tradisi nyepuh tersebut sarat akan nilai-nilai keislaman seperti pengungkapan rasa syukur kepada Allah swt, media silaturahmi (komunikasi) antara masyarakat setempat, hingga nilai filosofis yang secara implisit memuat pesan-pesan dakwah Islam yang berbasis budaya dan local wisdom. Tradisi nyepuh yang dilaksanakan oleh masyarakat Desa Ciomas setiap menjelang bulan Ramadhan, pada dasarnya adalah perpaduan antara ajaran-ajaran Islam dengan praktik budaya setempat. Fenenoma integrasi dan interlasi antara "agama" dan "budaya" tersebut, dapat dikaji dan diteliti dengan menggunakan pendekatan studi Antropologi. Menurut Koentjaraningrat (2015:15), secara praktis antropologi ialah ilmu yang mempelajari umat manusia pada umumnya dengan mempelajari aneka warna, bentuk fisik masyarakat, serta kebudayaan yang dihasilkannya. Berkaitan dengan kebudayaan yang dihasilkan oleh umat manusia, J.J. Hoenigman (1970:224) menyatakan bahwa ada tiga wujud kebudayaan, yaitu: 1) Gagasan (Ideafacts); 2) Karya (Artifact); dan 3) Sistem Sosial (Sociofact).

Setiap wujud kebudayaan yang ada pada masyarakat Ciomas, baik itu ideafacts, artifacts, dan sociofacts tidak bisa dipisahkan dari esensi dan substansi ajaran Islam. Entitas kebudayaan dan keislaman di daerah tersebut, tidak bisa dipisahkan satu sama lain, termasuk juga dalam budaya nyepuh. Menarik dan unik untuk dikaji lebih dalam, dari perspektif studi Dakwah Islam, budaya nyepuh tersebut sarat akan pesan-pesan keislaman yang disampaikan kepada masyarakat melalui rangkaian kegiatan dari budaya nyepuh tersebut. Budaya nyepuh yang sarat akan nilai-nilai keislaman ini masih bersifat implisit dan tertutup, maka dari itu perlu dilakukan penelitian untuk mengungkap secara lebih komprehensif dan inklusif tentang dimensi dakwah Islam dalam budaya nyepuh pada masyarakat Ciomas.

Realitas dan fenomena budaya nyepuh yang secara implisit banyak mengandung dimensi dakwah Islam, menjadi titik tolak dan landasan ilmiah untuk dilakukannya penelitian ini. Tiga wujud kebudayaan yang digagas oleh J.J. Hoenigman digunakan untuk memahami dan memetakan permasalahan dalam penelitian ini. Berdasarkan tiga wujud kebudayan tersebut, maka studi ini dibatasi pada tiga entitas permasalahan penelitian: Pertama, dimensi dakwah Islam dalam budaya nyepuh dilihat dari aspek ideafacts (gagasan masyarakat Ciomas). Kedua, dimensi dakwah Islam 
dalam budaya nyepuh dilihat dari aspek artifacts (karya masyarakat Ciomas). Ketiga, dimensi dakwah Islam dalam budaya nyepuh dilihat dari aspek sociofacts (sistem sosial masyarakat Ciomas).

Berlandaskan pada tiga wujud kebudayaan yang dikemukakan oleh J.J. Hoenigman, maka studi ini akan mencoba mengungkapkan secara lebih dalam tentang dimensi dakwah Islam dalam budaya nyepuh dilihat dari tiga aspek dasar, yakni: gagasan, karya, dan sistem sosial masyarakat desa Ciomas. Tiga aspek dasar kebudayaan tersebut, menjadi objek studi dalam meneliti dan mengungkap dimensi dakwah Islam dalam budaya nyepuh di Desa Ciomas. Berlatar belakang dari fenomena dan fakta yang telah diuraikan tersebut, menarik dan penting untuk dilakukan sebuah studi terkait dimensi dakwah Islam dalam budaya nyepuh masyarakat Desa Ciomas, Kecamatan Panjalu, Kabupaten Ciamis, Jawa Barat. Studi ini secara praksis, akan dapat memotret dan memetakan dinamika dan fenomena dakwah Islam yang berkembang dalam berbagai budaya yang ada di masyarakat. Hasil studi ini diharapkan dapat memberikan alternatif baru bagi metode dan model dakwah Islam yang lebih ramah budaya

\section{Metode Penelitian}

Studi ini termasuk pada jenis penelitian kualitatif. Lexy J. Moleong (1997:2) menyatakan bahwa penelitian kualitatif merupakan jenis penelitian yang bermaksud untuk memahami fenomena tentang apa yang dialami oleh subjek penelitian, misalnya perilaku, persepsi, motivasi, dan tindakan. Mengacu pada pernyataan Moleong tersebut, maka secara praktiknya studi ini akan memahami fenomena budaya Nyepuh masyarakat Ciomas yang memiliki nilai-nilai keislaman.

Metode yang digunakan dalam studi ialah studi kasus (case studies) (Mc. Millan, 1996:200). Menurut Jhon W. Creswell (2013:20), dari aspek praktiknya studi kasus merupakan strategi penelitian di mana di dalamnya peneliti menyelediki secara cermat suatu program, peristiwa, aktifitas, proses, atau sekelompok individu. Kasus-kasus dibatasi oleh waktu dan aktifitas, dan pengumpulan informasi secara lengkap dengan menggunakan berbagai prosedur pengumpulan data berdasarkan waktu yang telah ditentukan. Pemilihan metode studi kasus ini sangat relevan jika dilihat dari definisi metode studi kasus itu sendiri. Secara umum bahwa studi kasus merupakan penelitian yang dilakukan secara intensif terhadap suatu peristiwa dalam sebuah organisasi/kelompok individu. Dalam konteks studi ini, peristiwa yang ditelitinya adalah budaya Nyepuh, sedangkan kelompok individunya adalah masyarakat desa Ciomas. Maka dari itu, metode studi kasus sangat sesuai dan relevan untuk penelitian tentang dimensi dakwah Islam dalam budaya Nyepuh ini.

Mengacu pada Robert K. Yin (2012:103), maka pengumpulan data pada studi menggunakan tiga teknik, yaitu: observasi, wawancara, dan dokumentasi. Teknik observasi dilakukan dengan cara mengamati sembilan objek observasi yang meliputi: (1) Space (wilayah desa Ciomas); (2) Actor (masyarakat desa Ciomas); (3) Activity (kegiatan Nyepuh desa Ciomas); (4) Object (artifak desa Ciomas); (5) Act (tindakan masyarakat desa Ciomas); (6) Event (rangkaian kegiatan Nyepuh); (7) Time (waktu kegiatan Nyepuh); (8) Goal (tujuan kegiatn Nyepuh); (9) Felling (emosi dan ekspresi masyarakat desa Ciomas). Pada praktiknya, indepth interview (wawancara mendalam) dilakukan dengan cara menggali informasi melalui dialog dari beberapa warga masyarakat Desa Ciomas yang menjadi informan utama. Dokumen yang dijadikan data dalam penelitian ini dapat berupa gambar, tulisan, atau karya momental yang terkait dengan objek penelitian tentang dimensi dakwah Islam dalam budaya Nyepuh.

Studi ini berlandaskan pada teori Tiga Wujud Kebudayaan menurut J.J. Hoenigman yang terdiri dari ideafacts, artifacts, dan sosiofacts. Dari persekptif ilmu dakwah, landasan teori studi ini merujuk pada Murata \& Chittik (1997), Asep Muhyidin (2002), Endang Saefudin Anshari (2004), Ahmad Anas (2006), dan Enjang AS \& Aliyudin (2009) tentang dimensi pesan dakwah Islam. Secara umum, semua rujukan yang dijadikan landasan teori tentang pesan dakwah Islam dalam studi ini menyatakan bahwa ada enam jenis pesan dakwah Islam yang meliputi aqidah, ibadah, muamalah, akhlak, sejarah, dan ilmu pengetahuan lainnya. 


\section{Hasil Penelitian}

Budaya Nyepuh, secara historis awalnya disebut dengan acara Reuwahan dan Ngikis. Acara Reuwahan merupakan kegiatan bersih-bersih desa yang dilakukan oleh seluruh masyarakat Desa Ciomas. Acara tersebut dilakukan pada bulan Ruwah (Sya'ban), acara tersebut dilakukan sebanyak empat kali selama empat minggu dalam satu bulan. Minggu pertama dilaksanakan dengan kegiatan membersihakan susukan (bahasa Sunda, dalam bahasa Indonesia adalah selokan, kali, aliran sungai yang kecil) agar tidak ada sampah yang menyumbat serta dapat mengairi persawahan masyarakat; Minggu kedua, membersihkan jalan-jalan; Minggu ketiga, membersihakan tempat pemakaman umum; Minggu keempat, membersihkan makam keramat yang berada di hutan Geger Emas. Acara reuwahan pada minggu keempat merupakan kegiatan puncak.

Seluruh masyarakat Desa Ciomas berkumpul di hutan keramat dengan membawa makanan yang masih mentah di antaranya dagin ayam, daging sapi, daging kelinci, sayuran dan bumbu masak. Makanan tersebut dikumpulkan kemudian didoa'akan agar makanan itu memberikan keberkahan selama menjalankan puasa di bulan Ramahadhan. Makanan yang telah dido'akan itu kemudian dibawa pulang sebagai bahan makanan untuk disajikan ketika santap sahur dan berbuka puasa. Acara Reuwahan ini biasa dibarengi dengan kegiatan Ngikis. Ngikis adalah sebuah kegiatan membuat "pagar" dari bambu. Pagar dalam kegiatan Ngikis, secara filosofis memiliki makna untuk memagar (membentengi) tingkah laku atau perbuatan manusia dari segala hal yang tidak baik (Krisna, 2014:33). Kegiatan Ngikis ini dilaksanakan setiap satu tahun sekali pada bulan Sya'ban setelah selesai Shalat Nisfu Sya'ban. Kegiatan Reuwahan dan Ngikis tersebut, pada sekarang ini sudah tidak dilaksanakan oleh masyarakat Desa Ciomas dan berganti dengan budaya Nyepuh.

Beragam kegiatan budaya dan keagamaan yang dilakukan oleh masyarakat Desa Ciomas, pada dasarnya adalah untuk menjaga nilai-nilai yang diajarkan oleh para leluhur agar tetap terjaga dan terperlihara. Sesuai dengan apa yang diperintahkan oleh leluhur Desa Ciomas, bahwa masyarakat Desa Ciomas harus selalu membersihkan diri, baik jasmani dan rohani, dari hal-hal yang tidak baik. Tujuan diadakan budaya Nyepuh ini untuk menyambut bulan suci Ramadhan, agar mempersiapkan dan mensucikan diri secara lahir dan bathin. Eksistensi budaya Nyepuh ini sudah ada sejak zaman dahulu, dulu budaya Nyepuh ini merupakan bentuk tata krama memohon izin kepada Allah swt agar mendapat kemudahan, kekuatan dan keberkahan selama melaksanakan ibadah puasa. Seiring berkembangnya zaman, budaya Nyepuh ini menjadi salah satu kearifan lokal dan komoditas pariwisata Desa Ciomas; namun dimensi dakwah Islam yang terkandung dalam budaya Nyepuh tersebut masih eksis dan praksis sampai sekarang ini.

Kegiatan budaya Nyepuh ini laksanakan pada tanggal 15 dan 16 bulan Sya'ban. Satu hari sebelum dilaksanakan kegiatan tersebut, yakni pada tanggal 15 Sya'ban, ada beberapa rangkaian kegiatan yang dilaksanakan oleh masyarakat Desa Ciomas, yaitu: mulung pangpung, nalekan, ngasakan, bersih desa, nya'angan, dan pentas seni tradisional seperti karinding, celempungan, kacapi suling, serta gembyungan. Berikut penjelasan tentang beberapa bentuk rangkaian kegiatan budaya Nyepuh yang biasa dilakukan pada tanggal 15 Sya'ban, atau satu hari sebelum hari $\mathrm{H}$.
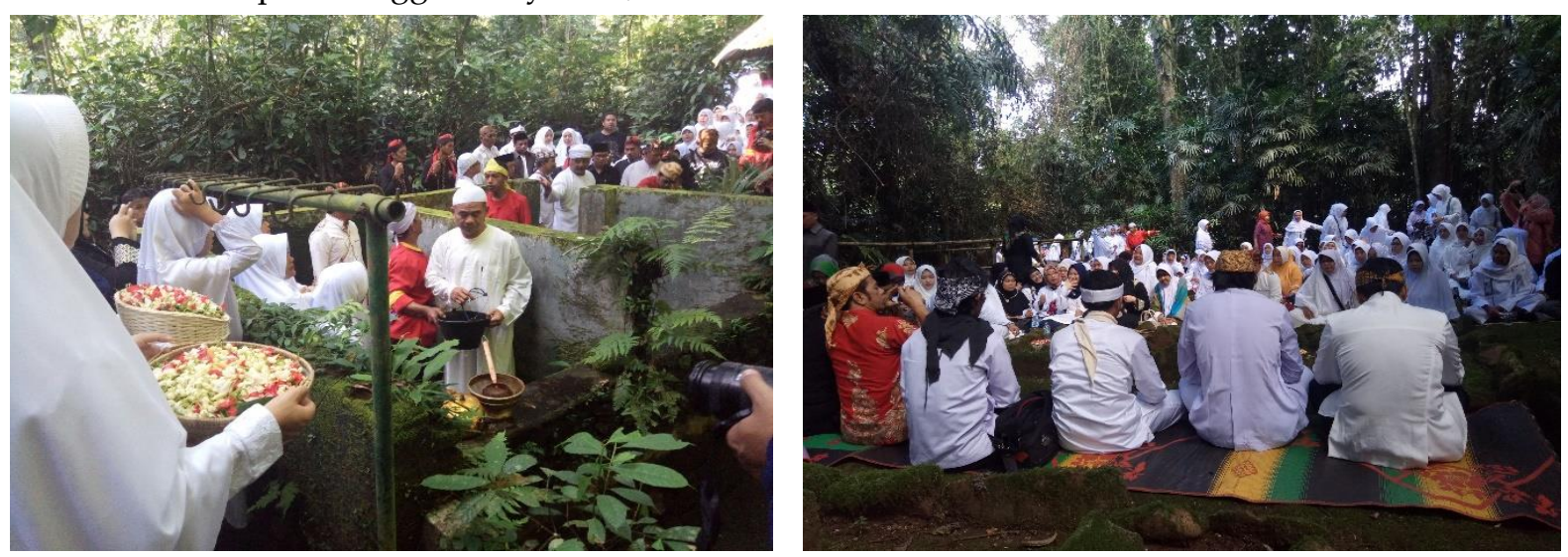

Gambar 1 Suasana Pelaksanaan Kegiataan Budaya Nyepuh 
Mulung Pangpung: Mulung (bahasa Sunda) adalah mengambil, dan Pangpung (bahasa Sunda) artinya kayu yang jatuh dari dahan pohon (biasanya dimanfaatkan untuk kayu bakar). Mulung pangpung secara praktis dapat diartikan dengan proses pengambilan kayu bakar. Pengambilan kayu bakar ini tidak boleh sembarangan dari hutan, harus mendapat izin dari penguasa hutan serta didampingi oleh kuncen setempat. Sebelum mengambil kayu bakar, ada ritual untuk "membuka hutan". Juru kunci "membuka hutan" agar terbuka untuk para pencari kayu, dengan cara melantunkan ayat suci al-Qur'an dan Shalawat Nabi serta berdo'a di sekitar makam keramat. Para pemuda yang melakukan mulung pangpung tersebut, tidak boleh mengambil kayu yang masih menempel apalagi yang masih tumbuh, harus kayu yang sudah jatuh dari pohon dengan sendiri. Sebelum para pemuda pencari kayu bakar pulang, pangpung yang diambil harus diperlihatkan terlebih dahulu kepada sesepuh desa. Pangpung yang sudah rapuh serta sudah berayap, tidak layak untuk digunakan dalam ngasakan (memasak), maka dari itu harus disimpan kembali ke hutan. Setelah kayu bakar yang dikumpulkan sudah layak digunakan untuk memasak, maka masuk pada tahapan selanjutnya yaitu nalekan.

Nalekan: merupakan ritual untuk menanyakan segala macam bahan dalam pembuatan makanan (ngasakan) dari berbagai macam bahan mentah untuk memamask, sampai proses pembuatannya harus sesuai dengan aturan adat. Kegiatan ini dilakukan setelah shalat Ashar di rumah Ema Iyam, salah satu sesepuh masyarakat, yang dipimpin langsung oleh juru kunci serta disaksikan para tokoh masyarkat. Bahan makanan yang diolah berasal dari pemberian masyarakat. Proses nalekan dilakukan kepada masyarakat yang memberikan bahan makanan untuk diolah. Pertanyaan tersebut berkenaan dengan asal-usul bahan makanan, seperti "apakah bahan makan dari hasil menanam di kebun sendiri?", "apakah membelinya menggunakan uang sendiri?", dan "dari mana asal uang tersebut?". Nalekan juga menanyakan "siapa yang akan memasak?", dan "apakah sudah mendapatkan ijin dari suami dan anaknya?". Selanjutnya masuk pada kegiatan ngasakan.

Ngasakan: dalam bahasa Indonesia, secara praktis dapat diartikan dengan memasak. Melanjutkan rangkaian sebelumnya, pada kegiatan ini bahan makan yang sudah terkumpul dari masyarakat dimasak menggunakan kayu bakar dan air yang diambil dari hutan Geger Emas. Ibu-ibu yang memasaknya harus yang sudah menopouse dan berjumlah 17 orang. Menurut keterangan masyarakat, jumlah 17 melambangkan banyak jumlah roka'at dalam Shalat Fardu. Selama proses memasak, tidak diperbolehkan untuk mengobrol atau melakukan hal-hal yang lain di luar kepentingan memasak.

Bersih Desa: Secara sederhana, kegiatan ini dapat diartikan dengan membersihkan desa dan menghias desa dengan bendera serta atribut lainnya. Kegiatan ini dilakukan oleh Bapak-Bapak dan pemuda Desa Ciomas secara gotong royong, dimulai membersihkan jalan, saluran air, halaman rumah masing-masing dan merapihakn lokasi utama acara Nyepuh, yaitu area makam keramat.

Nya'angan: berasal dari kata dasar Ca'ang (bahasa Sunda) yang berarti terang. Nya'angan dalam bahasa Indonesia berarti "menerangi". Nya'angan adalah kegiatan pawai obor yang dilakukan oleh masyarakat Desa Ciomas. Selama pawai obor tersebut, seluruh listrik di Desa Ciomas harus dipadamkan. Secara historis, kegiatan nya'ang ini untuk mengingatkan masyarakat Desa Ciomas pada zaman dahulu, ketika masih gelap gulita karena belum adanya listrik. Secara filosofis nya'angan mengisyaratkan bahwa dalam hidup manusia harus selalu melihat ke masa depan yang lebih cerah dan lebih baik, kemudian makna ca'ang (terang) ini juga mengisyaratkan bahwa hidup manusia harus selalu diterangi oleh cahaya al-Qur'an dan as-Sunnah.

Pentas Seni Tradisional: menjelang malam kegiatan dilanjutkan dengan pertunjukan seni tradisional yang berasal dari masyarakat Desa Ciomas. Pentas seni tradisional tersebut diadakan di halaman Bale Desa. Pentas seni diisi dengan pertunjukan seni tradisional seperti karinding, celempung, kacapi suling yang memainkan lagu-lagu Sunda yang sarat makna. Semua kesenian tradisional tadi dimainkan oleh generasi muda Desa Ciomas. Pentas seni ini ditutup dengan penampilan kesenian gambyungan yang dimainkan oleh para orang tua dengan menlantukan Shalawat dan Pujian kepada Bagida Nabi Muhammad saw. 
Budaya Nyepuh ini dilaksanakan Tanggal 16 Sya'ban 1440 H (22 April 2019 M). Tepat pada pukul 07:00 WIB seluruh masyarakat Desa Ciomas berkumpul di balandongan bale desa (halaman balai desa) untuk mengikuti acara pembukaan. Seluruh masyarakat Desa Ciomas dan yang mengikuti upacara adat ini, diwajibkan untuk menggunakan pakain yang berwarna putih. Menurut budaya setempat, warna putih memiliki makna kesucian dan kebersihan hati. Acara puncak dari budaya Nyepuh ini, tidak hanya diikuti oleh masyarakat setempat, tetapi juga oleh perangkat desa, jajaran kecamatan, Polsek, Koramil, aparat pemerintahan Kabupaten Ciamis serta para peziarah yang datang dari berbagai wilayah di luar Desa Ciomas. Berdasarkan hasil observasi, berikut ini uraian dari event (rangkaian kegiatan budaya nyepuh) yang dipaparkan berikut ini:

Pertama, persiapan. Kegiatan yang pertama, yaitu berangkatnya juru kunci, sesepuh desa, dan tokoh desa dari rumah juru kunci menuju balandongan bale desa. Masyarakat dan peziarah telah berkumpul di balandongan bale desa menunggu rombongan tersebut untuk melaksanakan pembukaan upacara adat budaya nyepuh.

Kedua, pembukaan. Masyarakat dan peziarah yang sudah berada di lokasi pembukaan dengan kompak melantunkan Shalawat yang dipimpin oleh Ustadz Dodo. Tepat pukul 07:00 WIB prosesi pembukaan dimulai. Pemandu acara melakukan pembukaan dengan membaca Basmallah. Setelah itu ada kata sambutan dari juru kunci diiringi dengan pembacaan tawasul dan dilanjutkan dengan pembacaan ayat suci al-Qur'an. Sambutan berikutnya disampaikan oleh Kepala Dea Ciomas. Disusul kemudian sambutan oleh Dinas Pariwisata dan Kebudayaan Kabupaten Ciamis sekaligus secara resmi membuka kegiatan budaya nyepuh. Setelah sambutan selesai disampaikan, maka prosesi pembukaan telah usai. Dilanjutkan pada prosesi selanjutnya, yaitu muka payung emas.

Ketiga, muka payung emas. Membuka payung emas ini dilakukan oleh Kepala Desa Ciomas, Camat Panjalu, dan Bupati Ciamis, di Balandongan Desa. Ada dua payung emas yang secara simbolis dibuka dalam rangkaian prosesi budaya nyepuh ini. Payung pertama dibuka dan disimpan di pintu gerbang bale desa Ciomas, dan payung kedua disimpan di rumah juru kunci. Membuka payung emas merupakan simbol bahwa kegiatan yang dilaksanakan mendapatkan perlindungan dari Allah swt. Membuka payung emas juga memiliki arti melindungi, mengayomi, seta menjadi teladan yang baik. Pembukaan payung emas yang dilakukan oleh para aparat pemerintahan tersebut, mengisyaratkan bahwa aparat pemerintahan harus bisa mengayomi dan melindungi masyarakat desa Ciomas secara khusus, dan seluruh rakyat Indonesia, secara umum.

Keempat, meungkeut nyere. Kegiatan ini dilakukankan dengan cara mengikat (meungkeut) batangbatang sapu lidi (nyere) sebagai simbol persatuan dan kesatuan; selain itu, agar setiap masyarakat dan peziarah mempunyai rasa yang tulus dan mempunyai visi yang sama ketika melakukan ziarah ke makam keramat, agar tidak melenceng, tidak mempunyai niat yang aneh-aneh, dan meminta hanya kepada Allah swt semata, bukan kepada orang yang telah meninggal. Setelah prosesi meungkeut nyere, dilanjutkan dengan irin-iringan, yakni berjalan dari bale desa menuju makan keramat Kyai Haji Panghulu Gusti di hutan Geger Emas.

Kelima, iring-iringan. Setelah rangkaian persiapan, pembukaan, muka payung emas, dan meungkeut nyere selesai, mulai memasuki ritual inti dari budaya nyepuh ini yaitu iring-iringan. Iringan-iringan adalah berjalan dari bale desa menuju makam keramat Kyai Haji Panghulu Gusti sejauh 3 kilo meter secara tertib dan beriringan. Barisan depan iring-iringan ini dipimpin oleh juru kunci, toko masyarakat, dan aparat pemerintahan; barisan tengah adalah masyarakat dan peziarah yang membawa bunga, sapu lidi, makanan, benih pohon, teko dan baskom yang nantinya digunakan untuk membawa ari dari hutan Geger Emas; dan barisan belakang adalah orang yang memainkan gambyung dengan Shalawat, salam, dan pujian-pujian kepada Baginda Nabi Muhammad saw.

Keenam, bebersih. Setelah sampai di hutan Geger Emas, iring-iringan harus melakukan ritual bebersih (membersihkan diri). Sebelum memasuki area makam, masyarakat dan peziarah diharuskan untuk membersihkan diri dengan cara berwudhu menggunakan air yang diambil dari sumur (mata air) keramat oleh juru kunci. Berwudhu merupakan simbol untuk membersihkan segala kotoran yang melekat pada diri, baik secara lahir dan bathin. Pengambilan air ini dilakukan oleh juru kunci. Air tersebut dimasukan ke dalam teko dan baskom untuk disiramkan ke pohon dan tanaman yang ada di 
area pemakaman dan hutan. Air yang telah diambil itu terlebih dahulu dibacakan do'a oleh juru kunci. Air yang telah dibacakan do'a dibawa pulang oleh masyarakat dan peziarah karena dipercaya mempunya khasiat yang sama dengan air zam-zam yang ada di Mekah. Setelah mengambil air dari mata air Geger Emas, prosesi selanjutnya adalah nyiraman.

Ketujuh, nyiraman. Prosesi ini adalah menyiram benih tanaman yang berasal dari sumbangan masyarakat dan peziarah. Prosesi nyiraman ini dilakukan dipimpin oleh apart Desa Ciomas dan Kecamatan Pajalu. Nyiraman ini memiliki makna harapan agar hasil bumi dapat tumbuh subur. Prosesi nyiraman yang dipimpin oleh aparat pemerintahan ini mengandung arti bahwa pemimpin harus memberikan contoh dan teladan yang bagi masyarakat. Air yang dipakai dalam nyiraman ini adalah air yang berasal dari hutan Geger Emas. Asal kata Ciomas sendiri merupakan gabungan kata dari "ci" (cai atau air) dan "omas" (berasal dari kata Emas, yakni hutan Geger Emas).

Kedepalan, muka konci. Setelah nyiraman sampailah pada acara puncak dari kebudaya nyepuh ini, yakni dan ziarah ke makam Kyai Panghulu Gusti yang berada dalam hutan Geger Emas. Sebelum ziarah, ada prosesi yang harus dilakukan terlebih dahulu yaitu, muka konci (membuka kunci, dalam artian membuka hutan Geger Emas). Iringan-iringan berjalan menuju ke area makam keramat dengan menaiki beberapa anak tangga. Selama menaiki anak tangga tersebut, masyarakat dan peziarah diwajibkan membaca Surat al-Ikhlas sebanyak tiga kali; selain membaca al-Ikhlas, masyarakat dan peziarah harus membaca Waqiatul Solihat, yakni ucapan: "Subhanaloh wal hamdulillah, wa laa ilaahailalloh wallahu akbar" pada saat berjalan di jalan yang datar. Setelah sampai di depan pintu gerbang makam keramat, kemudia juru kunci membaca, "Assalamu'alaikum Yaa Ahli Kubur", itulah yang disebut dengan muka konci, atau bisa diartikan memberi salam kepada penghuni makam, yakni Kyai Haji Penghulu Gusti. Kemudian, masuklah pada acara inti, yakni ziarah ke makam keramat.

Kesembilan, ziarah makam keramat. Setelah sampai di makam Kiyai Penghulu Gusti, maka dilakukanlah prosesi ziarah. Prosesi ziarah tersebut, di dalamnya ada tiga kegiatan yang harus dilakukan, yaitu: 1) Tawasul dan Hadiah Kubur; 2) Tausiyah; dan 3) Nyekar.

Kesepuluh, murak tumpeng. Selesai acara inti berupa ziarah makam keramat, seluruh masyarakat keluar dari area makam Kyai Penghulu Gusti menuju tanah lapang yang berada di dalam hutan Geger Emas. Acara selanjutnya yaitu makan bersama yang disebut dengan murak (membuka) nasi tumpeng. Ada tiga tumpeng utama yang telah disediakan, tiga tumpeng tersebut melambangkan makna rukun agama, yakni Iman, Islam, dan Ihsan. Setiap masing-masing tumpeng tersebut memiliki dua warna, yaitu warna putih terdapat pada bagian bawah tumpeng, dan warna kuning di bagian atas tumpeng. Selain makanan utama, ada juga makan lainnya seperti rangginang dan beubeutian. Beubeutian adalah makanan yang teridiri dari umbi-umbian.

Kesebelas, penutup. Mengakhiri rangkaian proses kegiatan budaya nyepuh ini dilakukan dengan cara tutup payung emas. Secara simbolis, dengan ditutupnya payun emas tersebut, maka berakhir pula rangkaian panjang budaya nyepuh ini.

Demikian gambaran objektif rangkaian budaya Nyepuh dari mulai persiapan, pembukaan, acara inti, hingga penutupan. Mengamati dari rangkaian acara tersebut, kegiatan budaya nyepuh ini sarat akan makna budaya dan keislaman. Dianalisis dari perspektif antropologi dan ilmu dakwah, budaya nyepuh ini memiliki banyak dimensi dakwah Islam yang berbasis budaya lokal. Dimensi dakwah dalam budaya nyepuh akan diungkapkan secara praksis pada bagaian hasil analisis dan pembahasan dalam studi ini. Sesuai dengan fokus permasalahan, maka hasil analisis dan pembahasan dalam studi ini, mengungkapkan dan menguraikan dimensi dakwah Islam yang terkandung dalam budaya nyepuh yang terbagi pada tiga aspek, yaitu: ideafact, artifact, dan sociofact.

\section{Dimensi Ideafact Dakwah Islam dalam Budaya Nyepuh}

Menarik dan penting untuk dianalisis, praktik kebudayaan berupa tradisi nyepuh yang dilestarikan oleh masyarakat Desa Ciomas, banyak memiliki wujud ideafact. Wujud ideafact tersebut dikaji dengan pendekatan ilmu dakwah mengandung banyak pesan dakwah yang sarat dengan nilainilai ajaran Islam yang bersifat universal dan global. Berdasarkan hasil observasi, ada beberapa wujud ideafact yang memiliki dimensi pesan dakwah Islam dalam tradisi nyepuh, yaitu: 
Pertama, prosesi mulung pangpung. Prosesi ini dalam persepektif pesan dakwah Islam, mengajarkan kepada umat manusia agar senantiasa merawat dan memelihara alam sekitar. Janganlah membuat kerusakan pada alam sekitar, karena pada esesnsinya alam telah memberikan kehidupan bagi umat manusia. Nilai moral dan religi yang tersirat dalam mulung pangpung dengan sangat jelas disitir dalam Q.S. ar-Ruum [30] ayat 41 dan Q.S. al-A'raf [7] ayat 56. Melihat dimensi ideafact dalam prosesi mulung pangpung ini, dalam persepektif maudu (pesan dakwah Islam), maka termasuk ke dalam kategori muamalah.

Kedua, prosesi nalekan. Ditinjau dari aspek maudu (pesan dakwah Islam) proses nalekan ini memiliki dimensi ideafact yang sangat prinsipil, yaitu anjuran mencari harta yang halal, dan memeprtanggung jawabkan harta yang telah dimiliki. Prosesi nalekan ini sangat sejalan dengan salah satu Hadits Nabi Muhammad saw, yaitu: "dari mana mendapatkan harta? dan untuk apa harta tersebut digunakan?". Prosesi nalekan ini juga, mengandung dimensi ideafact berupa gagasan dan perintah untuk bisa menjaga harta sebagai amanah dari Allah swt. Dimensi ideafact dalam proses nalekan ini termasuk ke dalam maudu dengan kategori ibadah.

Ketiga, prosesi ngasakan. Secara praktis, prosesi ini adalah kegiatan memasak 3 nasi tumpeng yang dilakukan oleh Ibu-Ibu yang berjumlah 17 orang. Secara simbolis, banyak ajaran Islam yang terkespresikan dalam prosesi memasak ini, yaitu: jumlah 17 melambangkan jumlah roka'at shalat fardu; 3 nasi tumpeng melambangkan Iman, Islam, dan Ihsan; tidak boleh mengobrol selama memasak melambangkan menjaga lisan; dan tidak boleh melakukan kegiatan lain di luar memasak melambangkan keistiqomahan terhadap tujuan yang hendak dicapai. Dimensi ideafact dakwah Islam dalam proses ngasakan ini sangat selaras dengan ajaran Islam secara substansial, seperti rukun agama, shalat fardu, menjaga lisan, dan istiqomah dalam hidup. Simbol yang terdapat dalam ngasakan ini masuk ke dalam maudu dengan kategori aqidah dan ibadah.

Keempat, prosesi bersih desa. Secara eksplisit prosesi dapat dilihat dengan pendekatan sosiologisantropologis dan religi. Prosesi bersih desa, dalam pandangan sosilogis-antropologis sangat berorientasi pada nilai-nilai sosial, budaya, dan kemasyarakatan. Prosesi ini mengajarkan bahwa untuk mencapai tujuan bersama, maka harus dilakukan usaha bersama secara kompak dan semangat. Prosesi bersih desa ini merupakan identitas asli bangsa Indonesia, yang di dalamnya terkandung nilai antropologis seperti budaya gotong-royong, bekerja sama, dan saling membantu. Prosesi bersih desa, dalam pandangan religi tentunya saja sangat sesuai dengan sunnah Nabi Muhammad saw, yang senantia harus selalu menjaga kebersihan, karena kebersihan merupakan indikator untuk melihat tingkat keimaan manusia, baik secara personal, maupun komunal. Dimensi ideafact yang tedapat dalam bersih desa merupakan maudu dalam entitas ahlak.

Kelima, prosesi nya'angan. Ada entitas simbolis, filosofis dan historis pada profesi pawai obor ini. Secara simbolis cahaya obor tersebut melambangkan cahaya al-Qur'an yang bisa menuntun manusia dari kondisi yang gelap (dzulumat) pada kondisi yang terang benderang (ila nur). Secara filosofis pawai obor ini memiliki ideafact optimisme, karena setiap manusia itu harus bisa melihat ke masa depan yang lebih cerah dan terang. Secara historis pawai obor ini bertujuan untuk mengingatkan kembali pada zaman gelap gulita karena belum adanya listrik. Lebih jauh dari itu, nya'angan berarti ngeunteungan prilaku hirup urang (berkaca pada tingkah laku pribadi). Aspek historis dalam nya'angan ini berupaya untuk mewujudkan rasa syukur kepada Allah swt karena telah diberikan kenikmatan berupa penerangan hidup dan pencerahan peradaban. Dimensi ideafact dalam prosesi pawai obor tersebut dari pandangan dakwah Islam masuk pada maudu dengan kategori aqidah, ibadah, dan sejarah.

Keenam, prosesi meungkeut nyere. Wujud ideafact dalam prosesi ini melambangkan persatuan, kesatuan, kerukunan, dan kerjasama. Melalui meungkeut nyere, diperingatkan agar tidak saling memusuhi, bercerai berai, dan berpecah belah. Prosesi meungkeut nyere meruapakan manifestasi dan simbolisasi dari Q.S. Ali Imran [3] ayat 103 tentang akan pentingnya persatuan dan larangan untuk bercerai berai. Menjaga persatuan dan kesatuan adalah wujud ideafact yang harus dipraktikan oleh setiap manusia yang hidup dalam lingkungan sosial. Makna yang terdapat dalam prosesi meungkeut nyere ini termasuk dalam maudu bertema akhlak. 
Berdasarkan hasil analisis terhadap enam prosesi yang sarat akan wujud kebudayan berupa idefact tersebut, dapat diketahui bahwa rangkaian prosesi yang dilaksanakan dalam kegiatan nyepuh banyak memuat pesan-pesan dakwah Islam yang bersifat universal dan global. Pesan-pesan dakwah Islam mejadi lebih "membumi" ketika disampaikan dengan cara menyesuaikan dengan tradisi dan budaya masyarakat setempat, seperti budaya nyepuh pada masyarakat Desa Ciomas. Mengamati fenomena akulturasi budaya dan agama dalam budaya nyepuh, maka dapat dsimpulkan bahwa dalam wujud ideafact budaya nyepuh memuat dimensi dakwah Islam. Kesimpulan ini dipertegas oleh beberapa narasumber dalam penelitian ini. Secara umum, narasumber menyatakan bahwa budaya nyepuh ini memang banyak memuat pesan-pesan dakwah dan ajaran-ajaran Islam. Berikut ini beberapa petikan wawancara dengan narasumber yang menguraikan secara lebih mendalam tentang budaya nyepuh yang banyak mempuat pesan dakwah Islam. Wahyu Karsana (Wawancara 1 September 2019), sesepuh Desa Ciomas sekaligus penasehat dalam setiap rangkaian kegiatan budaya nyepuh menjelaskan:

Dalam tradisi budaya nyepuh, memiliki makna dakwah Islam yang tersirat, yaitu sarat dengan makna, semua kegiatan budaya nyepuh, dari mulai mulung pangpung, nalekan, nguncenan yaitu nguncenkeun ka kasepuhan kakuncennan makam Kiyai Haji Panghulu Gusti. Semua kegiatan budaya nyepuh ini memilki ide yang biayasa, yaitu dapat mempertahankan budaya yang budaya lain bisa lapuk, hilang ditelan zaman, tetapi lain halnya dengan budaya nyepuh, yang dikemas sedemikan rupa, suapa tetap ada. Gagasan-gagasan yang dikeluarkannyapun mempunyi nilai filosofis, dan di dalam budaya nyepuh terdapat nilai-nilai keisalaman dan nilainilai kesundaan yang memang memiliki kedekatan, sama saja, nilai persaudaran nyaeta ukhuwah, nilai persatuan nyaeta umatan wahidatan, dan nilai kacintaan atawa mahabab ka Alloh, Kanjeng Nabi, dan para Alim Ulama.

Perkembangan budaya nyepuh dari tahun ke tahun semaking berkembangan dengan banyaknya peziarah dan wisatawan yang datang dari berbagai daerah untuk menyaksikan secara langsung budaya nyepuh tersebut. Perkembangan tersebut, tidak merubah esensi dari budaya nyepuh. Berdasarkan hasil penelusuran dan analisis terhadap data-data hasil observasi, bahwa ada tiga wujud ideafact dari budaya nyepuh ini. Ketiga wujud tersebut mengandung dimensi dakwah Islam yang sampai saat ini masih eksis dan lestari. Adapun tiga wujud ideafact tersebut ialah: (1) Nyepuhkeun nu tos ngawitan. Memiliki makna bahwa budaya nyepuh merupakan pengawal jalan kebaikan yang diawali oleh para pendahulu yang telah menyebarkan agama Islam. Tradisi ini sudah berlangsung selama puluhan tahun yang digelar di Desa Ciomas sebagai penghormatan terhadap amanah Kiyai Haji Penghulu Gusti, supaya generasi muda belajar kepada orang yang lebih tua atau sepuh agar lebih baik untuk menghadapi kehidupan di masa depan. (2) Nyepuhkeun panyipuhan urang. Artinya mengukur perjalanan kehidupan sebagai timbal bailk yang dikhususkan kepada diri antara anak terhadap orang tua, generas penerus terhadap generasi tua, dan pimpinan dengan bawahan. Budaya nyepuh ini diharapakan dapat mempermudah masalah-masalah sosial yang dihadapi dan memperoleh solusi yang terbaik, sesuai dengan sambung rasa sebagai ajang silturahmi yang dilakukan di makan Kiyai Haji Penghulu Gusti. (3) Nyepuhkeun mapag ramadhan. Kegiatan ini sebagai persiapan untuk menjelang bulan suci Ramadhan, oleh karena itu di bulan yang penuh berkah tersebut seluruh umat Islam melaksanakan ibadah puasa. Sebelum melaksanakan ibadah puasa tersebut, harus membersihakan diri secara lahir dan bathin.

Demikian hasil analisis dan pembahasan tentang dimensi idefact dakwah Islam dalam budaya nyepuh. Bahasan selanjutnya adalah menganalisis dan menguraikan tentang dimensi artifact dakwah Islam dalam budaya nyepuh. Bahasan wujud artifact, akan banyak menganalisis wujud benda kebudayaan yang dipakai selama proses kegiatan budaya nyepuh di Desa Ciomas.

\section{Dimensi Artifact Dakwah Islam dalam Budaya Nyepuh}

Didasarkan atas hasil pengamatan, banyak artifact (benda-benda budaya) dalam rangkaian kegiatan dan tradisi budaya nyepuh; jika dianlisis lebih dalam dengan pendekatan antropologi 
dakwah, maka artifact tersebut memiliki dimensi dakwah Islam yang secara tersirat maupun tersurat memuat nilai-nilai ajaran Islam yang filosofis dan praktis. Berikut ini adalah pembahasan mengenai artifact dari rangkaian kegiatan budaya nyepuh yang memiliki dimesi dakwah Islam:

Pertama, makam keramat Kyai Haji Panghulu Gusti. Artifact primer yang terdapat dalam budaya nyepuh di Desa Ciomas tentu saja ialah sebuah makam keramat tempat dikebumikan tokoh penyebar Islam di wilayah Panjalu, yakni Kyai Haji Panghulu Gusti. Makam yang dikeramatkan oleh masyarakat Desa Ciomas tersebut, berada di hutan Geger Emas, maka dari itu makam keramat itu juga sering disebut "Makam Keramat Geger Emas" atau "Makam Gede". Makam keramat ini menjadi artifact utama di Desa Ciomas, karena adanya budaya nyepuh itu sendiri adalah untuk menghormati dan mengenang tokoh yang dimakamkan di hutan Geger Emas. Seperti yang telah dijelaskan sebelumnya, bahwa puncak dari kegiatan budaya nyepuh adalah prosesi ziarah ke makam keramat Kiyai Penghulu Gusti, maka dari itu dapat simpulkan bahwa makam keramat inilah yang menjadi wujud kebudayaan dalam bentuk artifact yang menjadi ciri khas tradisi budaya nyepuh di Desa Ciomas, Kecamatan Panjalu, Kabupaten Ciamis.

Kedua, mata air Geger Emas. Peninggalan budaya yang masih lestari sampai sekarang ialah sebuah mata air yang berada dalam hutan Geger Emas. Artifact dalam bentuk mata air ini memiliki keunikan, yaitu tidak pernah penuh (meluber) pada saat musim hujan, dan tidak pernah kering pada saat musim kemarau. Berdasarkan hasil penggalian informasi pada beberapa narasumber, bahkan nama "Ciomas" sendiri secara historis berasal dari air Geger Emas ini. Kata "Ci" dalam bahasa Indonesia berarti "air", dan kata "Omas" terambil dari kata "emas" yang berasal dari nama "Geger Emas", maka dari jika diartikan nama desa "Ciomas" ialah "air dari hutan Geger Emas", yang merujuk pada sumber mata air. Menarik dan penting untuk diungkap, masyarakat desa Ciomas sangat mempercayai bahwa sumber mata air Geger Emas berasal dari air zam-zam yang dibawa langsung oleh Kiyai Panghulu Gusti dari tanah suci Mekkah. Berdasarkan cerita yang berkembang di masyarakat, Kyai Gede (sebutan lain untuk Kiyai Panghulu Gusti) pernah menuntut ilmu ke Arab Saudi, dan ketika datang ke Ciamis ia membawa air zam-zam dengan gayung yang bolong, kemudian air tersebut ditumpahkan di tiga tempat yang berbeda yaitu Ciomas, Panjalu, dan Gunung Syawal. Hinga sekarang, mata air yang berada di Ciomas menjadi pusat dari tiga tempat ditumpahkannya air zam-zam yang dibawa ole Kyai Gede. Mata air Geger Emas yang menjadi wujud artifact yang nyata di Desa Ciomas ini, secara simbolis dan filosofis memiliki dimensi dakwah Islam yang terkandung di dalamnya. Dimensi dakwah yang paling penting dalam artifact mata air Geger Emas ini adalah upaya melestarikan dan menjaga alam serta lingkungan. Entitas tersebut sangat selaras dengan anjuran agama Islam tentang larangan membuat kerusakan di muka bumi. Terlebih lagi dalam konteks ajaran Islam, hubungan antara manusia dengan alampun telah diatur dengan baik, hal tersebut terwujud dalam tridialektika hubungan manusia, yaitu: hablum minallah, hablum minanaas, dan hablum minal 'alam. Dimensi pesan dakwah Islam dalam artifact berupa mata air Geger Emas ini termasuk ke dalam maudu dalam kategori muamalah.

Ketiga, pangpung atau kayu bakar yang khusus dipergunakan untuk memasak tumpeng dan makanan lain dalam acara nyepuh. Pangpung ialah kayu yang jatuh dari dahan pohon, kayu tersebut oleh masyarakat Desa Ciomas biasanya dimanfaatkan untuk kayu bakar. Ada hal yang unik dalam wujud artifact ini, pangpung atau kayu bakar yang diguankan dalam tradisi nyepuh harus berasal dari hutan Geger Emas, tidak boleh dari tempat lain, kemudian cara mengambilnyapun tidak sembarangan, ada beberapa tahapan yang harus dilakukan; begitu juga dengan pangpung yang diambilnya, tidak boleh asal mengambil, tapi harus benar-benar yang sudah jatuh dari pohon dan mengering, jangan yang masih tumbuh dan menempel di dahan pohon. Setelah pangpung terkumpul, tidak langsung dibawa untuk bahan bakar, tetapi harus izin terlebih dahulu pada sesepuh Desa. Ada entitas yang menarik dan penting dalam prosesi pengambilan kayu bakar dari hutan ini (mulung pangpung), yaitu sebelum mengambil kayu bakar di hutan Geger Emas terlebih dahulu harus membaca ayat suci al-Qur'an dan melantukan Shalawat Nabi di dalam hutan. Fenomena tersebut, sudah sangat jelas bahwa dalam pengambilan kayu bakar ini sarat akan nilai-nilai Islam, dibuktikan dengan begitu menghargainya masyarakat Desa Ciomas kepada alam, sehingga dalam 
memanfaatkan hasil alam tersebut tidak lupa untuk membaca al-Qur'an dan Shalawat Nabi sebagai ekspresi pengagungan dan syukur kepada Allah swt. Manusia sebagai makhluk ayang dianugerahi akal dan pikiran oleh Allah swt sudah seharunya bisa menjaga dan melestarikan lingkungan serta alam sekitar; karena lingkungan dan alam adalah nikmat yang paling besar yang Allah swt berikan kepada umat manusia. Hasil alam yang melimpah ruah telah dimanfaatkan oleh manusia dan makhluk Allah lainnya. Hasil alam ini tidak dapat dihitung oleh akal manusia, maka dari itu manusia harus mensyukurinya. Wujud artifact berbentuk pangpung dalam kegiatan nyepuh ini, sekali lagi mengandung dimensi pesan dakwah Islam tekait dengan menjaga dan melestarikan lingkungan.

Keempat, nasi tumpeng dalam prosesi murak tumpeng pada budaya nyepuh. Secara umum, wujud artifact berupa nasi tumpeng ini ada pada setiap daerah di Indonesia; namun secara khusus nasi tumpeng yang digunakan untuk acara makan bersama dalam nyepuh Desa Ciomas ini memiliki keunikan dan makna tersendiri. Nasi tumpeng yang disajikan dalam sesi makan bersama setelah ziarah makam keramat, harus berjumlah 3 buah. Menarik untuk diungkap, jumlah tiga pada sajian nasi tumpeng tersebut ternyata melambakan tiga entitas penting dalam agama Islam, yaitu: Iman, Islam, dan Ihsan. Tiga entitas tersebut, dalam ajaran Islam sering disebut dengan arkanul ad-Din (rukun agama). Tiga entitas tersebut, oleh Murata \& Chitik disebut Trilogi Islam. Keunikan lain dari artifact nasi tumpeng dalam budaya nyepuh ini adalah orang yang membuatnya. Para pembuat nasi tumpeng ini, tidaklah sembarangan haruslah memenuhi kriteria yang ditentukan. Orang yang membuat nasi tumpeng ini harus seorang perempuan yang sudah menopose berjumlah 17 orang dan mendapatkan ijin dari suami dan anaknya. Selama proses pembuatannya, 17 orang tersebut tidak diperbolehkan untuk mengobrol, dan bersenda gurau. Berdasarkan hasil penelusuran, bahwa jumlah 17 melambangkan jumlah roka'at dalam sholat fardhu. Dianalisis lebih dalam, ada banyak dimensi dakwah Islam yang terdapat dalam nasi tumpeng ini, terutama dalam proses pembuatannya. Selama proses pembuatannya, Ibu-Ibu tidak boleh mengobrol dan bersenda gurau, hal ini mengandung maksud bahwa umat Islam harus bisa menjaga lisannya, menghindari dari perkatan kotor dan tidak ada gunannya; selain itu, larangan untuk tidak mengerjakan sesuatu di luar memasak selama prosesi ngasakan mendidik manusia agar istiqomah dan fokus untuk mencapai tujuan yang telah direncanakan. Wujud artifact berupa nasi tumpeng ini banyak memiliki dimensi pesan dakwah di dalamnya. Secara rinci dimensi dakwah Islam dalam tumpeng tersebut adalah: (1) Rukun agama Islam: Iman, Islam, dan Ihsan; (2) Anjuran untuk melaksanakan shalat fardu; (3) Menjaga lisan; (4) Istiqomah dalam berkerja. Dimensi dakwah Islam yang terdapat dalam artifact tumpeng tersebut masuk ke dalam maudu: ibadah, muamalah, dan akhlak.

Kelima, colen atau obor yang terbuat dari bambu yang dipakai dalam prosesi nya'angan (pawai obor) pada malam hari sebelum pelaksanaan nyepuh. Di tengah kemajuan zaman yang sudah modern seperti ini, masyarakat Desa Ciomas masih tetap mempertahankan kearifan lokal berupa obor yang terbuat dari batang bambu. Bukan hanya sekedar obor bambu, colen mempunyai makna khusus bagi masyarakat Desa Ciomas. Makna tersebut terdiri dari aspek historis, filosofis, dan simbolis. Secara historis, colen merupakan pengingat identitas sejarah Desa Ciomas yang pada zaman dahulu belum mendapat aliran listrik. Colen menjadi sumber penerangan primer pada saat itu. Makna ini menjadi ungkapan rasa syukur atas kondisi zaman sekarang yang sudah serba terang, berbeda dengan zaman dahulu ketika para orang tua masyarakat Desa Ciomas hidup dalam kondisi gelap gulita. Secara filosofis, colen memiliki arti yang sangat futuristik. Obor api dari bambu ini mengisyaratkan kepada manusia bahwa harus tetap fokus menyongosng masa depan yang cerah; Secara simbolis, cahaya api yang berasal dari colen tersebut melambangkan cahaya al-Qur'an dan asSunnah yang harus diikuti oleh setiap umat Muslim. Wujud artifact berupa colen ini memiliki nilai filosofis dan simbolis yang cukup mendalam. Colen, pada dasarnya mengajarkan kepada umat manusia, khususnya umat Islam, agar selalu membaca dan mengamalkan al-Qur'an; karena hanya dengan membaca al-Qur'an hidup manusia akan terbimbing dan terarahkan pada cahaya keridhaan Allah swt. Secara praksis, orang yang istiqomah membaca al-Qur'an juga akan dimudahkan oleh Allah swt untuk mencapai kesuksesa di masa depan. Dimensi pesan dakwah Islam dalam artifact 
obor bambu (colen) ini adalah isyarat untuk terus membaca dan mengamalkan al-Qur'an. Maudu yang terkandung dalam artifact obor bambu (colen) masuk dalam kategori ibadah.

Keenam, nyere atau batang sapu lidi yang digunakan dalam prosesi meungkeut nyere pada rangkaian kegiatan nyepuh. Nyere atau batang lidi ini memiliki dimensi simbolis dan filosofis yang sangat dalam. Sapu lidi biasaya digunakan untuk membersihkan halaman rumah dari kotoran dan sampah, jika hanya satu batang lidi yang digunakan untuk membersihkan pekarang tersebut, maka akan sulit membersihkannya; sedangkan lidi-lidi yang sudah digabungkan menjadi satu kesatuan yang membentunk sapu, maka akan dapat digunakan secara efektif dan efisien. Sapu lidi yang hanya satu batang, tidak punya kekuatan dan mudah dipatahkan, namun setelah digabungkan dengan beberapa batang lidi lainya, lidi menjadi alat yang bermanfaat dan tidak mudah untuk dipatahkan. Mengamati aspek praksis dari sapu lidi tersebut, nyere yang digunakan dalam prosesi meungkeut nyere, secara simbolis dan filosofis melambangkan kesatuan dan kekuatan; sebaliknya, nyere tersebut melarang masyarakat untuk bercerai-berai apalagi sampai berselisih dan bermusuhan. Diantara nilai yang dijungjung tinggi oleh bangsa Indonesia tertuang dalam falsafah, "bersatu kita teguh, bercerai kita runtuh". Maka dari itu, artifact batang lidi ini memiliki makna kesatuan dan persatuan. Dikaji dari perspektif ilmu dakwah, makna yang terkandung dalam artifact batang lidi tersebut memiliki dimensi pesan keislaman yang tercantum secara tegas dalam Q.S. Ali Imran [3] ayat 103 tentang perintah Allah swt untuk persatuan dan larangan untuk bercerai berai. Dimensi dakwah Islam yang terdapat dalam wujud artifact dari nyere ini termasuk dalam maudu muamalah.

Ketujuh, beubeutian atau umbian-umbian dari hasil kebun masyarakat Desa Ciomas yang disajikan dalam prosesi makan bersama setelah kegiatan nyepuh. Beubeutian bukan merupakan makanan ini dalam kegiatan nyepuh, tapi beubeutian ini menjadi pelengkap makanan dan mempunyai peran penting dalam acara nyepuh. Beubeutian hasil kebun masyarakat ini disimpan di samping tumpeng yang menjadi makan utama dalam nyepuh. Beubeutian berasal dari kata beuti (bahasa Sunda) dalam bahasa Indonesia berarti tanaman umbi-umbian. Maka dari itu, beubeutian dari hasil kebun yang disediakan untuk prosesi murak tumpeng terdiri dari ubi dan singkong. Beubeutian, walaupun hanya sebagai makanan pelengkap, tetapi artifact ini memiliki dimensi pesan dakwah Islam yang membumi. Beubeutian yang berasal dari hasil kebun masyarakat Desa Ciomas, memiliki makna religius yang terkandung di dalamnya. Masyarakat Desa Ciomas secara sukarela memberikan hasil kebunnya untuk acara nyepuh tersebut. Berdasarkan fakta yang didapatkan, bahwa tujuan masyarakat memberikan umbi-umbian hasil kebunnya sebagai bentuk ungkapan rasa syukur kepada Allah swt atas nikmat hasil alam yang diberikan. Masyarakat Desa Ciomas mempercayai, bahwa dengan membagikan hasil bumi kepada masyarakat lain, akan menambah keberkahan terhadap hasim bumi tersebut. Mengamati fenomena tersebut, sudah sangat jelas dalam ajaran Islam entitas tersebut merupakan realisasi dari Q.S. Ibraim [14] ayat 7. Dimensi dakwah Islam yang terdapat dalam bebeutian termasuk maudu dengan kategori ibadah, muamalah, dan akhlak.

Demikian uraian hasil analisis dan pembahasan tentang benda-benda budaya (artifact) dalam budaya nyepuh yang mengandung nilai, makna, dan dimensi pesan dakwah Islam. Uraian berikutnya adalah hasil analisis dan pemabahasan tentang wujud kebudayaan sociofact yang mengandung dimensi dakwah Islam.

\section{Dimensi Sociofact Dakwah Islam dalam Budaya Nyepuh}

Membahas tentang wujud sociofact dalam budaya nyepuh, pada setiap rangkaian kegiatannya memuat banyak sistem sosial, baik yang berhubungan dengan masyarakat dan para peziarah, lingkungan dan alam, serta dengan Allah swt sebagai sang pencipta. Berdasarkan hasil observasi secara menyeluruh, rangkaian prosesi kegiatan dalam budaya nyepuh tersebut membentuk sociofact (sistem sosial) dalam masyarakat Desa Ciomas. Sociofact di Desa Ciomas terklasifikasi ke dalam tiga bentuk utama, yaitu: hubungan antar masyarakat, hubungan dengan alam, dan hubungan dengan Tuhan. Berikut uraian dan pembahasan tentang tiga bentuk sociofact yang ada di Desa Ciomas:

Pertama, hubungan dengan manusia. Bentuk sociofact yang pertama ini menggambarkan pola hubungan antara sesama manusia yang terjadi pada masyarakat Desa Ciomas. Melalui budaya 
nyepuh, sistem sosial dan hubungan masyarakat Desa Ciomas terjalin dengan baik. Budaya nyepuh menjadi peneguh identitas sosial masyarakat Desa Ciomas yang menjujung tinggi nilai-nilai local wisdom seperti melestarikan tradisi, gotong royong, saling menghormati, dan semangat berbagi. Sociofact dengan bentuk hubungan antar masyarakat Desa Ciomas dalam budaya nyepuh ini dapat ditemukan dalam prosesi kegiatan: Bersih Desa, Pentas Seni, Iring-Iringan, Tausiyah, dan Murak Tumpeng. Semua prosesi tersebut, pada aspek sociafact sangat berorientasi pada hubungan kemanusian yang terjadi diantara masyarakat Desa Ciomas. Wujud kebudayaan berupa sociofact hubungan manusia, memiliki dimensi dakwah Islam yang disebut dengan hablum minanaas. Pesan dakwah yang tedapat dalam sociofact hubungan antar masyarakat ini termasuk kedalam maudu dengan kategori akhlak.

Kedua, hubungan dengan alam. Bentuk sociofact yang kedua ini menggambarkan hubungan manusia dengan alam. Masyarakat Desa Ciomas yang mayoritas bertani dan berkebun, sangat menjaga dan merawat lingkungan dan alam yang ada di Desa Ciomas. Budaya nyepuh sendiri pada dasarnya merupakan ungkapan rasa syukur kepada Allah swt atas nikmat alam dan anugerah hasil bumi yang selama ini dimanfaatkan oleh masyarakat Desa Ciomas. Ada beberapa rangkaian prosesi kegiatan budaya nyepuh yang menyiratkan penghargaan masyarakat Desa Ciomas terhadap alam, diantaranya: Nya'angan, Mulung Pangpung, Meungkeut Nyere, dan Nyiraman. Semua prosesi tersebut menunjukkan bahwa manusia benar-benar harus menjaga dan menghormati alam dengan cara melestarikannya dan jangan membuat kerusakan terhadapnya. Wujud kebudayaan berupa sociofact hubungan dengan alam, memiliki dimensi dakwah Islam yang disebut dengan hablum minal alam. Pesan dakwah yang tedapat dalam sociofact hubungan dengan alam ini termasuk kedalam maudu dengan kategori muamalah.

Ketiga, hubungan dengan Tuhan. Bentuk sociofact yang ketiga ini menggambarkan hubungan manusia dengan Tuhan. Masyarakat Desa Ciomas yang mayoritas beragama Islam, sangat menjungjung tinggi dan mengedepankan nilai-nilai keisalaman, termasuk dalam budaya nyepuh. Budaya nyepuh ini pada esensinya merupakan ungkapan rasa syukur kepada Allah swt atas segala anugerah yang diberikan kepada Desa Ciomas. Nilai keislaman lain yang menjadi esensi budaya nyepuh adalah mengenang sekaligus wujud terimakasih kepada Kiyai Haji Panghulu Gusti yang telah menyebarkan agama Islam di wilayah Panjalu, khususnya di Desa Ciomas. Sociofact hubungan antara manusia dengan Tuhan dalam budaya nyepuh terlihat pada prosesi kegiatan: Ngasakan, Beberesih, Muka Konci, Ziarah, Tawasul, dan Nyekar. Wujud kebudayaan berupa sociofact hubungan dengan Tuhan, memiliki dimensi dakwah Islam yang disebut dengan hablum min Allah. Pesan dakwah yang tedapat dalam sociofact hubungan dengan Tuhan ini termasuk kedalam maudu dengan kategori Akidah.

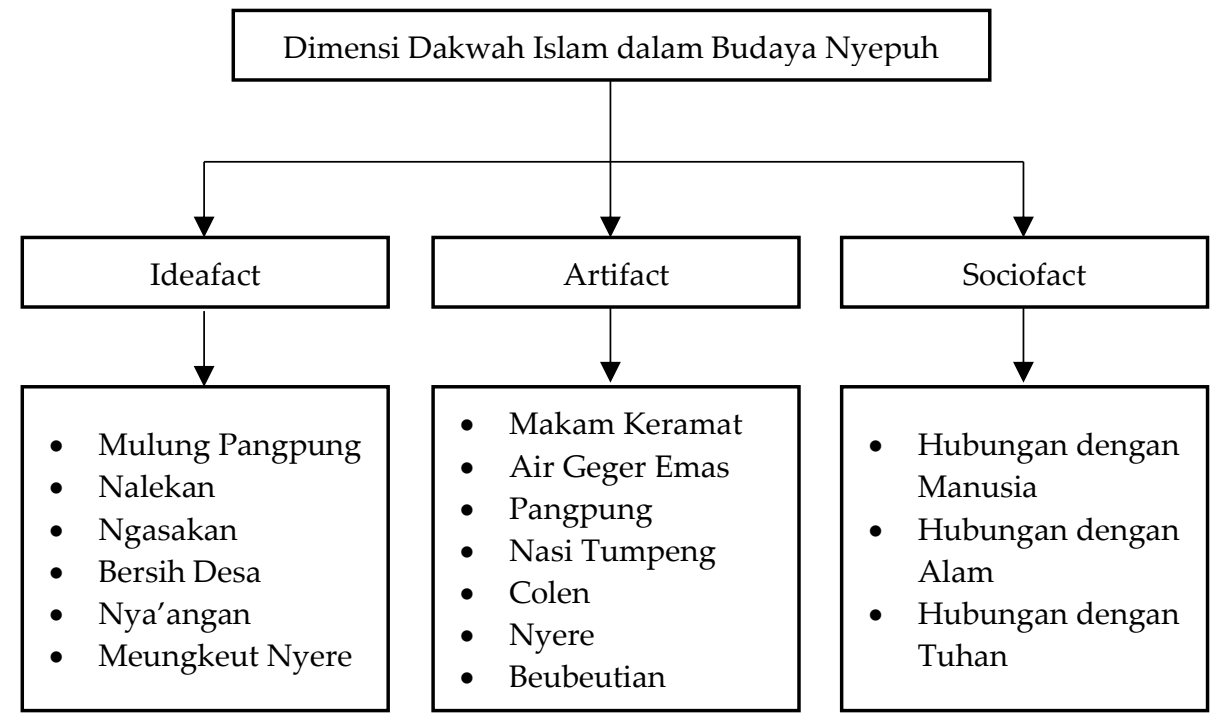

Gambar 2. Kerangka Hasil Analisis dan Pembahasan 
Demikian uraian hasil analisis dan pembahasan tentang sistem sosial yang terbentuk karena adanya budaya nyepuh di Desa Ciomas. Wujud kebudayaan berupa sociofact dalam budaya nyepuh banyak memuat dimensi dakwah Islam. Secara keseluruhan, budaya nyepuh di Desa Ciomas ini banyak memuat dimensi dakwah Islam. Setiap wujud kebudayaan yang terdiri dari ideafact, artifact, dan sociofact sangat sarat dengan pesan-pesan (maudu) dakwah Islam. Mempermudah temuan, hasil analisis, dan pembahasan penelitian, maka secara skematis dapat digambarkan seperti gambar 2 .

\section{Kesimpulan}

Wujud kebudayaan berupa artifact dalam budaya nyepuh banyak memuat dimensi pesan dakwah Islam. Artifact dalam budaya nyepuh yang banyak memuat dimensi dakwah dapat dilihat dari benda fisik: Makam Keramat, Air Geger Emas, Pangpung, Nasi Tumpeng, Colen, Nyere, dan Beuebeutian. Ketiga, dimensi sociofact dakwah Islam dalam budaya nyepuh. Berdasarkan temuan penelitian dan hasil analisis, wujud kebudayaan berupa sociofact dalam budaya nyepuh penuh dengan dimensi pesan dakwah Islam. Sociofact dalam budaya nyepuh yang penuh denngan dimensi dakwah dapat diamati dari bentuk sistem sosial: Hubungan dengan Manusia, Hubungan dengan Alam, dan Hubungan dengan Tuhan. Penelitian ini berlandaskan teori antropologi dari J.J. Hoenigman tentang tiga wujud kebudayaan. Direkomendasikan melakukan penelitian lanjutan yang lebih mendalam dan holistik tentang budaya nyepuh di Desa Ciomas dengan menggunakan berbagai teroi dan perspektif ilmu yang berbeda, seperti perspektif ilmu komuinkasi, sosiologi, maupun psikologi. Hasil penelitian ini secara praktis dapat diterapkan dalam melaksanakan aktifitas dakwah Islam yang masih berinterelasi dengan tradisi dan budaya setempat. Direkomendasikan bagi para da'i maupun lembaga dakwah Islam agar senantiasa melakukan aktifitas dakwah yang ramah budaya.

\section{Referensi}

Anas, A. (2006). Paradigma Dakwah Kontemporer. Semarang: Pustaka Rizki.

Anshari, E. S. (2004). Wawasan Islam: Pokok-Pokok Pikiran tentang Paradigma dan Sistem Islam. Jakarta: Gema Insani Pers.

Creswell, J. W. (2013). Research Design: Qualitative, Quantitave, and Mixed. California: Sage Publishing.

Enjang AS \& Aliyudin. (2009). Dasar-Dasar Ilmu Dakwah. Bandung: Widya Padjajaran.

Hakim, S. L. (2017). Tabligh Berbasis Budaya (Studi Kasus pada Budaya Nyepuh di Desa Ciomas Kecamatan Panjalu Kabupaten Ciamis). Bandung: UIN Sunan Gunung Djati.

Hoenigman, J. J. (1970). The World of Man. New York: Sage Publishing.

Koentjaraningrat. (2015). Pengantar Ilmu Antropologi. Jakarta: Rineka Cipta.

Kristna, A. (2004). Unsur Semiotika Dina Tradisi Nyepuh di Desa Ciomas Kecamatan Panjalu Kabupaten Ciamis Pikeun Bahan Pangajaran Maca Artikel di SMA. Ciamis: Dinas Pendidikan.

Mc.Millan, J. H. (1996). Educational Research: Fundamentas for the Consumer. HarperCollins: HaperCollins Publishers Inc.

Moleong, L. J. (1997). Metode Penelitian Kualitatif. Bandung: Rosdakarya.

Muhyidin, A. (2002). Metode Pengembangan Dakwah, Bandung: Pustaka Setia.

Murata, S. \& Chitik, W. C. (1995). The Vision of Islam. USA: Paragon House.

Nurhadi, D. F. (2015). Teori-Teori Komunikasi: Teori Komunikasi dalam Perspektif Penelitian Kualitatif. Bogor: Ghalia Indonesia.

Rahman, M. T. (2018). Pengantar filsafat sosial. LEKKAS.

Rahman, T. (2013). 'Indianization' of Indonesia in an Historical Sketch. International Journal of Nusantara Islam, $1(2), 56-64$.

Ritchie, P. M., \& Hatoum, R. (2020). Creation and legacy of historic silences in anthropological traditions: An ethnohistorical re-analysis of nineteenth-century Coast Salish genealogy, leadership, and territoriality. History and Anthropology, 1-29.

Wijaya, Y. \& Wulan, A. (2014). Tradisi Nyepuh di Desa Ciomas Kecamatan Panjalu Kabupten Ciamis, Jurnal Artefak, 2 (1).

Yin, R. K. (2012). Case Study Research: Design and Methond. London: Sage Publishing.

(C) 2021 by the authors. Submitted for possible open access publication under the terms and conditions of the Creative Commons Attribution (CC BY SA) license (https://creativecommons.org/licenses/by-sa/3.0/). 